\title{
Twenty-Eight Years of the Collegiate Aviation Review: An Exploratory Study of Academic Research in Aviation Education
}

\author{
Timm J. Bliss \\ Oklahoma State University
}

\begin{abstract}
The author conducted a review of academic journal articles published in the Collegiate Aviation Review (CAR). The study included all 189 articles published in the CAR over the past 28 years (1983-2010). The author categorized the CAR articles by author's institution/organization affiliation, classification by subject category, and geographical grouping of contributing authors and institutions/organizations. The study indicates that the $C A R$ has a broad range of authors and subject matter. Collegiate flight training curriculum and instructional methods, collegiate aviation degree programs, the collegiate aviation student, the airport system, and the commercial airline industry were the top 5 subject areas over the past 28 years. Implications and opportunities are provided for the future and the role of aviation faculty and industry professionals engaged in aviation education research. The findings of this exploratory study provide additional opportunities for research initiatives in the aviation education environment.
\end{abstract}

\section{Introduction}

In 1947, the National Association of University Administrators of Aviation Education (NAUAAE) was organized in Denver, Colorado "to encourage and expand the growth and status of aviation education programs nationwide" (University Aviation Association, 2011a). In 1948, the NAUAAE held their first Annual Meeting in conjunction with Denver Air Congress, when NAUAAE adopted their first mission statement:

It is believed that the work of the Association, conducted as it will be by leading educators of the United States, will be of basic and permanent benefit to aviation. A new generation of youth, graduating from the high schools and colleges each year, with a thorough grounding in and understanding of the airplane and its social, scientific, political, and economic influences upon living will, through the years, establish an informed public opinion on aviation which will go far toward eliminating many of the present day problems which beset the aviation industry and the national defense (University Aviation Association, 2011a).

In 1949, the National Association of University Administrators of Aviation Education changed their name to the University Aviation Association (UAA) and headquarters were established at United Airlines School and College Service (UASCS) in Chicago, Illinois. Approximately 30 years later, in 1977, UAA moved their headquarters to the Auburn University-owned airport in Auburn, Alabama (University Aviation Association, 2011a). 
When the UAA moved to Auburn, association membership totaled 178 individual members and the annual budget for UAA was \$5,000 (University Aviation Association, 2011a). In 2010, the UAA had 500 members and an annual organizational budget of \$310,500 (C. Williamson, personal communication, November 14, 2011).

According to the CAR's Statement of Objectives "the UAA is the only professional organization representing all levels of the non-engineering/technology element in collegiate aviation education" (Fanjoy, 2008, p. 6). The UAA achieves its goals through several objectives:

- Encourage and promote the attainment of the highest standards in aviation education at the college level.

- Provide a means of developing a cadre of aviation experts who make themselves available for such activities as consultation, aviation program evaluation, speaking assignments, and other professional contributions that stimulate and develop aviation education.

- Furnish a national vehicle for the dissemination of knowledge relative to aviation among institutions of higher education and governmental and industrial organizations in the aviation/aerospace field.

- Foster the interchange of information among institutions that offer non-engineering oriented aviation programs including business technology, transportation, and education.

- Support aviation/aerospace-oriented teacher education with particular emphasis on the presentation of educational workshops and the development of educational materials in the aviation and aerospace fields (Fanjoy, 2008, p. 6).

In 1938, the University Aviation Association initiated its first “call for papers" to provide an opportunity for collegiate aviation faculty to gain national recognition through a competitive peer-review process. In the acknowledgments section of the 1983 conference proceedings, Editor James M. Daley stated,

The papers presented in this volume demonstrate that the members of the Association continue to grow in terms of their knowledge and their research. This reflects well, not only on the members of the University Aviation Association, but serves as a benchmark for future members and old members to surpass; it seems true that, academically, we either grow or we die (p. iii).

From 1983-1990, the scholarly papers were published as University Aviation Association Fall Conference Proceedings; the first Collegiate Aviation Review (CAR) was published in 1991 after a call for papers was announced at the UAA conference in 1990 (McCoy, 1991).

The purpose of this study was to review the individual contributions to the CAR that have provided growth to the UAA over the past 28 years and to reflect upon what the 
future may hold for this aviation professional organization and its scholarly journal, the $C A R$. This is important to ensure the UAA and its membership is academically positioned to meet the ever-changing aviation/aerospace industry and address the continuing challenges of the $21^{\text {st }}$ century.

\section{Method}

A review of 189 CAR articles from 1983 to 2010 was conducted by the author. Specifically, the articles published in the CAR were categorized by author's institution/organization affiliation, classification by subject category, and geographical grouping of contributing authors and institutions/organizations. The methodology used in this study to explore the contribution of authors to the $C A R$ was very similar to one used by the author to analyze the content and contributions of another peer-reviewed professional journal (Woods et al., 1989). This exploratory study identified and categorized aviation faculty and industry professionals who have led the aviation profession, academically, and what important issues and challenges they have identified in their scholarly writings over the past 28 years.

\section{Results}

Table 1 represents the 28-year timeline of CAR publications, which was divided into five-year increments (1983-1985 represents only three years) to highlight author and article productivity from 1983-2010. During the 2001-2010 decade, 60\% of all CAR articles were published. In addition, 118 co-authors contributed to these $C A R$ publications. During the period of 2006-2010, there were 73 articles (39\% of total articles) published in the CAR. Beginning in May 2007, the editors began publishing the $C A R$ biannually in the spring and fall resulting in the proliferation of published articles during this five-year span.

Table 1. Timeline of Published CAR Articles, 1983-2010

\begin{tabular}{ccccc}
\hline Years & Journal Articles & Percent of Articles & Total Article Pages & Co-Authors \\
\hline \hline & & & & \\
$1983-1985$ & 14 & 7.40 & 252 & 3 \\
$1986-1990$ & 19 & 10.05 & 388 & 4 \\
$1991-1995$ & 17 & 9.00 & 140 & 11 \\
$1996-2000$ & 25 & 13.23 & 334 & 17 \\
$2001-2005$ & 41 & 21.70 & 536 & 44 \\
$2006-2010$ & 73 & 38.62 & 905 & 154 \\
Total & 189 & 100.00 & 2555
\end{tabular}




\section{Authorship by Institution/Organization Affiliation}

The CAR articles are categorized in Table 2 by author's institution/organization affiliation. Similar to the Woods et al. (1989) article, columns 1, 2 and 3 in Table 2 list institutions/organizations, their rank by number of articles, and total articles per institution/organization, respectively. Every time a lead (first) author and/or co-author represented a specific educational institution or aerospace/aviation organization, that institution or organization was credited with a journal article. As a result, there were 189 articles published with 154 co-authors therefore the total number of CAR "authorcredited" articles in Table 2 is 343, which is significantly larger than the actual number of articles (189) published in the CAR from 1983-2010 (University Aviation Association, 2011c). As shown in Table 2, Southern Illinois University Carbondale was credited with 79 of 343 author-credited articles (lead and/or co-author) and ranked first in total articles published in the CAR from 1983-2010.

Columns 4, 5, and 6 (Table 2) ranked contributing institutions/organizations by total number of pages for lead (first) authors only. The author recorded the institution/organization affiliation of the lead author, credited the institution/organization for the entire number of article pages contributed to the $C A R$, and lastly, ranked all institutions/organizations by total page numbers. For example, Embry-Riddle Aeronautical University was credited with 194 total pages and ranked second overall.

The last three columns in Table 2 ranked the institutions/organizations by total article pages for all authors. Each institution/organization was credited with a percentage of total pages when there was more than one contributing author associated with a $C A R$ article. Therefore, the total number of $C A R$ pages $(2,555)$ was apportioned among all contributing authors. Over the 28-year time period studied by the author, 54 different institutions/organizations and one non-affiliation were represented by the contributing authors publishing in the $C A R$.

All in all, 197 authors contributed to the CAR during the 28-year time period, 19832010; 131 authors contributed only once, 35 authors contributed twice as senior or coauthor, 8 authors contributed three times, 13 authors contributed four times, 1 author contributed six times, 6 authors contributed five times, 1 author contributed seven times, 1 author contributed nine times, and 1 author (David NewMyer from Southern Illinois University Carbondale) contributed 14 times to the $C A R$, ten times as lead author and four times as co-author.

Table 3 lists the institution/organization sources of the 343 CAR author-credited articles. Educational institutions (universities and colleges) were first with 332 articles, or $97 \%$ of total articles. Non-academic organizations were responsible for a very small percentage of total articles ( 3 percent) published in the $C A R$. These non-academic 
Table 2. Institution/Organization Affiliation of Collegiate Aviation Review Authors, 1983-2010

\begin{tabular}{|c|c|c|c|c|c|c|c|c|}
\hline \multirow[b]{2}{*}{ Institution/Organization } & \multicolumn{2}{|c|}{$\begin{array}{c}\text { Journal } \\
\text { Articles }^{1}\end{array}$} & \multicolumn{3}{|c|}{ Lead Author ${ }^{2}$} & \multicolumn{3}{|c|}{ All Authors ${ }^{3}$} \\
\hline & Rank & Number & Rank & Pages & Percent & Rank & Pages & Percent \\
\hline Southern Illinois & & & & & & & & \\
\hline $\begin{array}{l}\text { University } \\
\text { Middle Tennessee State }\end{array}$ & 1 & 79 & 1 & 557 & 21.80 & 1 & 553.00 & 21.64 \\
\hline $\begin{array}{l}\text { University } \\
\text { Purdue }\end{array}$ & 2 & 31 & 4 & 158 & 6.18 & 4 & 160.67 & 6.29 \\
\hline $\begin{array}{l}\text { University } \\
\text { Auburn }\end{array}$ & 3 & 24 & 5 & 134 & 5.24 & 5 & 134.00 & 5.24 \\
\hline $\begin{array}{l}\text { University } \\
\text { Embry-Riddle Aeronautical }\end{array}$ & 4 & 22 & 3 & 175 & 6.85 & 3 & 163.50 & 6.40 \\
\hline $\begin{array}{l}\text { University } \\
\text { University of North }\end{array}$ & 5 & 18 & 2 & 194 & 7.59 & 2 & 186.34 & 7.29 \\
\hline Dakota & 6 & 17 & 7 & 120 & 4.70 & 6 & 120.00 & 4.70 \\
\hline University of Nebraska & 7 & 16 & 6 & 128 & 5.01 & 7 & 115.50 & 4.52 \\
\hline $\begin{array}{l}\text { Arizona State University } \\
\text { Oklahoma State }\end{array}$ & 8 & 15 & 11 & 65 & 2.54 & 11 & 66.01 & 2.58 \\
\hline $\begin{array}{l}\text { University } \\
\text { St. Cloud State }\end{array}$ & 9 & 14 & 10 & 67 & 2.62 & 9 & 75.33 & 2.95 \\
\hline $\begin{array}{l}\text { University } \\
\text { Central Washington }\end{array}$ & 10 & 11 & 16 & 42 & 1.64 & 17 & 42.00 & 1.64 \\
\hline University & 11 & 9 & 12 & 63 & 2.47 & 12 & 63.00 & 2.47 \\
\hline $\begin{array}{l}\text { Indiana State University } \\
\text { Bowling Green State }\end{array}$ & 11 & 9 & 13 & 51 & 2.00 & 13 & 51.00 & 2.00 \\
\hline $\begin{array}{l}\text { University } \\
\text { Florida Institute of }\end{array}$ & 11 & 9 & 8 & 99 & 3.87 & 8 & 104.00 & 4.07 \\
\hline $\begin{array}{l}\text { Technology } \\
\text { Parks College of Saint Louis }\end{array}$ & 14 & 8 & 15 & 46 & 1.80 & 15 & 46.00 & 1.80 \\
\hline University & 15 & 5 & 21 & 31 & 1.21 & 21 & 31.00 & 1.21 \\
\hline San Jose State University & 16 & 4 & 19 & 38 & 1.49 & 16 & 43.00 & 1.68 \\
\hline Rocky Mountain College & 16 & 4 & 9 & 74 & 2.90 & 10 & 74.00 & 2.90 \\
\hline $\begin{array}{l}\text { Wichita State University } \\
\text { University of }\end{array}$ & 16 & 4 & 37 & 11 & 0.43 & 23 & 26.50 & 1.04 \\
\hline $\begin{array}{l}\text { Illinois } \\
\text { Hampton }\end{array}$ & 19 & 3 & 22 & 30 & 1.17 & 22 & 30.00 & 1.17 \\
\hline University & 20 & 2 & 18 & 40 & 1.57 & 19 & 40.00 & 1.57 \\
\hline Western Michigan & 20 & 2 & 43 & 8 & 0.31 & 38 & 8.00 & 0.31 \\
\hline
\end{tabular}




\begin{tabular}{|c|c|c|c|c|c|c|c|c|}
\hline \multirow[b]{2}{*}{ Institution/Organization } & \multicolumn{2}{|c|}{$\begin{array}{l}\text { Journal } \\
\text { Articles }^{1}\end{array}$} & \multicolumn{3}{|c|}{ Lead Author ${ }^{2}$} & \multicolumn{3}{|c|}{ All Authors ${ }^{3}$} \\
\hline & Rank & Number & Rank & Pages & Percent & Rank & Pages & Percent \\
\hline \multicolumn{9}{|l|}{ University } \\
\hline $\begin{array}{l}\text { Kent State University } \\
\text { Hillsborough County Aviation }\end{array}$ & 20 & 2 & 36 & 12 & 0.47 & 41 & 7.66 & 0.30 \\
\hline Authority & 20 & 2 & 17 & 41 & 1.60 & 18 & 41.00 & 1.60 \\
\hline Daniel Webster College & 20 & 2 & 27 & 17 & 0.67 & 27 & 17.00 & 0.67 \\
\hline Non-affiliated Author ${ }^{4}$ & 25 & 1 & 23 & 25 & 0.98 & 24 & 25.00 & 0.98 \\
\hline $\begin{array}{l}\text { Ohio State University } \\
\text { Harvard }\end{array}$ & 25 & 1 & 27 & 17 & 0.67 & 27 & 17.00 & 0.67 \\
\hline University & 25 & 1 & 24 & 19 & 0.74 & 25 & 19.00 & 0.74 \\
\hline $\begin{array}{l}\text { Western Oklahoma State } \\
\text { College }\end{array}$ & & & & & & & & \\
\hline Advanced Aviation & 25 & 1 & 43 & 8 & 0.31 & 52 & 4.00 & 0.16 \\
\hline $\begin{array}{l}\text { Concepts } \\
\text { California State }\end{array}$ & 25 & 1 & 39 & 10 & 0.39 & 45 & 5.00 & 0.20 \\
\hline $\begin{array}{l}\text { University } \\
\text { American }\end{array}$ & 25 & 1 & 46 & 6 & 0.23 & 44 & 6.00 & 0.23 \\
\hline $\begin{array}{l}\text { Airlines } \\
\text { United States Air Force }\end{array}$ & 25 & 1 & 20 & 33 & 1.29 & 20 & 33.00 & 1.29 \\
\hline $\begin{array}{l}\text { Academy } \\
\text { Texas Southern }\end{array}$ & 25 & 1 & 24 & 19 & 0.74 & 35 & 9.50 & 0.37 \\
\hline $\begin{array}{l}\text { University } \\
\text { Nova Southeastern }\end{array}$ & 25 & 1 & 33 & 14 & 0.55 & 32 & 14.00 & 0.55 \\
\hline $\begin{array}{l}\text { University } \\
\text { Eastern Michigan }\end{array}$ & 25 & 1 & 29 & 16 & 0.63 & 29 & 16.00 & 0.63 \\
\hline University & 25 & 1 & 24 & 19 & 0.74 & 25 & 19.00 & 0.74 \\
\hline $\begin{array}{l}\text { Sky Views } \\
\text { University of New }\end{array}$ & 25 & 1 & 41 & 9 & 0.35 & 50 & 4.50 & 0.18 \\
\hline Orleans & 25 & 1 & 39 & 10 & 0.39 & 45 & 5.00 & 0.20 \\
\hline Florida State University & 25 & 1 & 45 & 7 & 0.27 & 42 & 7.00 & 0.27 \\
\hline Ohio University & 25 & 1 & 29 & 16 & 0.63 & 38 & 8.00 & 0.31 \\
\hline $\begin{array}{l}\text { Delta State University } \\
\text { Vaughn College of }\end{array}$ & 25 & 1 & 29 & 16 & 0.63 & 29 & 16.00 & 0.63 \\
\hline $\begin{array}{l}\text { Aeronautics } \\
\text { Joint Interagency Task }\end{array}$ & 25 & 1 & 37 & 11 & 0.43 & 34 & 11.00 & 0.43 \\
\hline $\begin{array}{l}\text { Force } \\
\text { University of Western }\end{array}$ & 25 & 1 & 35 & 13 & 0.51 & 43 & 6.50 & 0.25 \\
\hline Ontario & 25 & 1 & 41 & 9 & 0.35 & 36 & 9.00 & 0.35 \\
\hline Miami Dade Community & 25 & 1 & 14 & 48 & 1.88 & 14 & 48.00 & 1.88 \\
\hline
\end{tabular}




\begin{tabular}{|c|c|c|c|c|c|c|c|c|}
\hline \multirow{2}{*}{ Institution/Organization } & \multicolumn{2}{|c|}{$\begin{array}{l}\text { Journal } \\
\text { Articles }^{1}\end{array}$} & \multicolumn{3}{|c|}{ Lead Author ${ }^{2}$} & \multicolumn{3}{|c|}{ All Authors ${ }^{3}$} \\
\hline & Rank & Number & Rank & Pages & Percent & Rank & Pages & Percent \\
\hline \multicolumn{9}{|l|}{ College } \\
\hline \multicolumn{9}{|l|}{ Broward County Comm } \\
\hline College & 25 & 1 & 33 & 14 & 0.55 & 32 & 14.00 & 0.55 \\
\hline \multicolumn{9}{|l|}{ University of South } \\
\hline Alabama & 25 & 1 & 32 & 15 & 0.59 & 31 & 15.00 & 0.59 \\
\hline \multicolumn{9}{|l|}{ Federal Aviation } \\
\hline Administration & 25 & 1 & & & & 45 & 5.00 & 0.20 \\
\hline Utah State University & 25 & 1 & & & & 52 & 4.00 & 0.16 \\
\hline Bryant College & 25 & 1 & & & & 55 & 1.66 & 0.06 \\
\hline United States Air Force & 25 & 1 & & & & 48 & 4.67 & 0.18 \\
\hline \multicolumn{9}{|l|}{ University of West } \\
\hline Florida & 25 & 1 & & & & 49 & 4.66 & 0.18 \\
\hline \multicolumn{9}{|l|}{ Central Missouri State } \\
\hline University & 25 & 1 & & & & 38 & 8.00 & 0.31 \\
\hline Concordia University & 25 & 1 & & & & 51 & 4.50 & 0.18 \\
\hline \multicolumn{9}{|l|}{ Philadelphia International } \\
\hline Airport & 25 & 1 & & & & 52 & 4.00 & 0.16 \\
\hline \multirow{2}{*}{$\begin{array}{c}\text { Texas Tech University } \\
\text { Totals }\end{array}$} & 25 & 1 & & & & 37 & 8.50 & 0.33 \\
\hline & & 343 & & 2555 & 100.00 & & 2555.00 & 100.00 \\
\hline \multicolumn{9}{|c|}{$\begin{array}{l}{ }^{1} \text { An institution/organization was credited with a } C A R \text { article each time a lead (first) author and/or a co- } \\
\text { author representing that institution/organization contributed to the journal. Therefore, there was double } \\
\text { counting each time two or more authors contributed to an article. As a result, the total number of "author- } \\
\text { credited" articles (343) is inconsistent with the actual number of CAR articles (189) published from 1983- } \\
2010 \text { (Woods et al., 1989). }\end{array}$} \\
\hline \multicolumn{9}{|c|}{$\begin{array}{l}{ }^{2} \text { The lead author columns list the pages and percent of contribution by lead (first) author only. The lead } \\
\text { author's institution/organization affiliation was recorded and received credit for the entire number of article } \\
\text { pages contributed in the CAR. Lastly, the institutions/organizations were ranked by total number of article } \\
\text { pages contributed by lead author only (Woods et al., 1989). }\end{array}$} \\
\hline \multicolumn{9}{|c|}{$\begin{array}{l}{ }^{3} \text { Each contributing institution/organization listed in the all authors columns was credited with a percentage } \\
\text { of total pages in the } C A R \text { article. Fractional counting occurred each time two or more authors contributed to } \\
\text { an article. Final calculations resulted in identical results for the total pages contributed by lead authors and } \\
\text { total pages by all authors }(2,555) \text { (Woods et al., 1989). }\end{array}$} \\
\hline $\begin{array}{l}{ }^{4} \text { One author contributil } \\
\text { grouped alone and repı }\end{array}$ & $\begin{array}{l}\text { the } C A \\
\text { ted in } \mathrm{t}\end{array}$ & $\begin{array}{l}\text { vas not a } \\
\text { entry. }\end{array}$ & ed wit & n insti & n/organ & Thi & thor was & \\
\hline
\end{tabular}


Table 3. Institution/Organization Source of Collegiate Aviation Review Articles, 1983 to 2010

\begin{tabular}{lcc}
\hline \multicolumn{1}{c}{ Institution/Organization } & Journal Articles & Percent of Total Articles \\
\hline \hline & & \\
Universities and Colleges & 332 & 96.80 \\
U.S. Airport Systems & 3 & 0.88 \\
U.S. Military & 2 & 0.58 \\
U.S. Government & 2 & 0.58 \\
Aviation Companies & 2 & 0.58 \\
U.S. Commercial Airlines & 1 & 0.29 \\
Non-affiliated Author & 1 & 0.29 \\
\cline { 2 - 3 } \multicolumn{1}{c}{ Total } & 343 &
\end{tabular}

organizations included airport systems, military, aviation companies, commercial airlines, and the government.

\section{Article Classification by Subject Category}

In Table 4, the $C A R$ articles are classified in 15 different subject categories. These categories, determined by the author of this study, were based on each CAR article's title, abstract, and content. The subject category "collegiate flight training curriculum and instructional methods" accounted for 37 CAR articles and 492 pages, or 19\% of total pages. The remaining top five subject categories included collegiate aviation degree programs, the collegiate aviation student, the airport system, and the commercial airline industry. These diverse subject categories (Table 4) characterize the research initiatives of the contributing authors to the CAR over the past 28 years.

\section{Geographical Grouping of Contributing Author's Institution/Organization}

The contributing author's institution/organization is grouped geographically in Figure 1. The nine regions (Alaska, Northwest Mountain, Western Pacific, Great Lakes, Central, Southwest, New England, Eastern, and Southern) identified in Figure 1 are the operational regions used by the Federal Aviation Administration (Federal Aviation Administration, 2011). Authors associated with institutions/organizations located in the Great Lakes region contributed 159 of 343 author-credited CAR articles (46\%) from 1983-2010; and authors associated with institutions/organizations from the Southern region contributed 90 articles (26\%). Smaller contributions came from authors associated with institutions/organizations located in the Central region (8\%), Southwest region (6\%) and the Western Pacific region (6\%).

Only 340 of the $343 C A R$ author-credited articles are grouped geographically in Figure 1 because two $C A R$ articles were written by authors associated with international 
Table 4. Subject Classification of Collegiate Aviation Review Articles, 1983 to 2010.

\begin{tabular}{|c|c|c|c|}
\hline Category & $\begin{array}{c}\text { CAR } \\
\text { Articles }\end{array}$ & Pages & $\begin{array}{c}\text { Percent of } \\
\text { Total } \\
\text { Pages } \\
\end{array}$ \\
\hline $\begin{array}{l}\text { Collegiate Flight Training Curriculum and } \\
\text { Instructional Methods Including Flight Simulation }\end{array}$ & 37 & 492 & 19.26 \\
\hline $\begin{array}{l}\text { Collegiate Aviation Degree Programs } \\
\text { (2-year and 4-year degree programs) }\end{array}$ & 20 & 284 & 11.11 \\
\hline $\begin{array}{l}\text { The Collegiate Aviation Student (characteristics, } \\
\text { accountability, perceptions and learning styles) }\end{array}$ & 20 & 230 & 9.00 \\
\hline The Airport System and Air Traffic Control & 15 & 225 & 8.81 \\
\hline The Commercial Airline Industry & 14 & 154 & 6.03 \\
\hline The Aviation/Aerospace Industry & 13 & 200 & 7.83 \\
\hline $\begin{array}{l}\text { Academic Internships, Cooperative Programs and } \\
\text { Articulation Agreements }\end{array}$ & 12 & 153 & 5.99 \\
\hline Assessment \& Accreditation & 11 & 143 & 5.59 \\
\hline Distance Learning and Technology & 10 & 121 & 4.73 \\
\hline $\begin{array}{l}\text { Collegiate Aviation "Non-Flight” Curriculum } \\
\text { (aviation and airport management, aviation safety) }\end{array}$ & 9 & 175 & 6.85 \\
\hline Employment in the Aviation Industry & 7 & 112 & 4.38 \\
\hline Women and Minority Aviation Students & 7 & 68 & 2.67 \\
\hline Aviation Faculty & 6 & 90 & 3.52 \\
\hline U.S. Government \& Military & 5 & 71 & 2.78 \\
\hline International Aviation Issues & 3 & 37 & 1.45 \\
\hline Total & 189 & 2555 & 100.00 \\
\hline
\end{tabular}




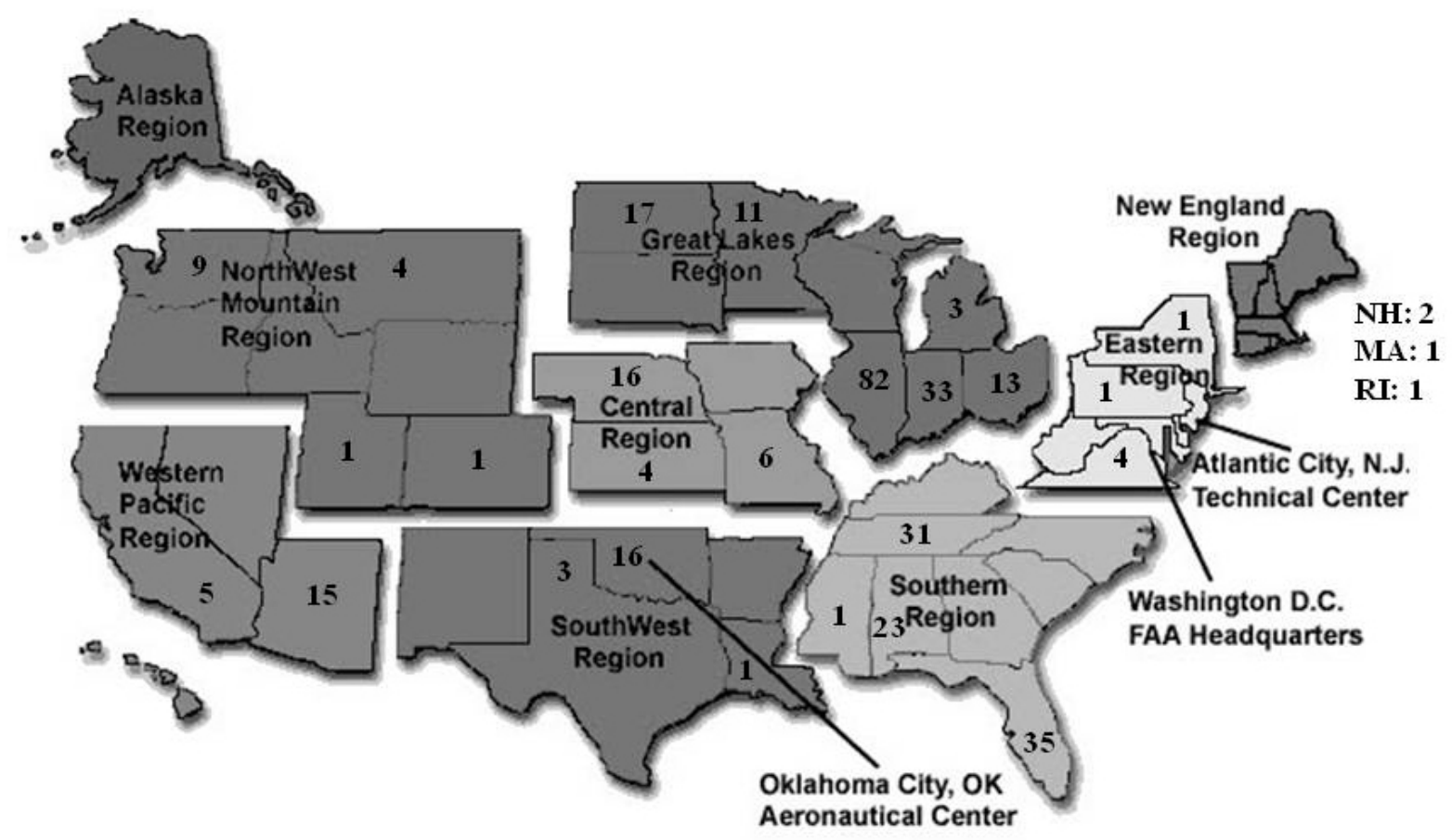

Figure 1. Geographical Grouping of CAR Author’s Institution/Organization $1983-2010$

institutions/organizations and the one remaining $C A R$ article was written by an author not affiliated with an institution/organization.

The institution/organization membership of the University Aviation Association is grouped in geographical regions in Table 5. There were 98 institution/organization memberships listed in the 2010 UAA membership directory; and 94 (96\%) of these institutions/organizations were located in the United States (University Aviation Association, 2011b). Twenty-two of these U.S. institution/organization memberships (22\%) are located in the Great Lakes region (North Dakota, South Dakota, Minnesota, Wisconsin, Michigan, Illinois, Indiana, and Ohio) and 17 institution/organization memberships (17\%) come from the Southern region (Kentucky, Tennessee, North Carolina, South Carolina, Mississippi, Alabama, Georgia, and Florida). As shown in Table 5, authorship of total CAR publications was heavily representative of these same regions. Lastly, there is very little international representation of institutional membership; only four percent.

\section{Summary of Results}

The blind peer-reviewed Collegiate Aviation Review has been published for 28 years with the first seven years being published as blind peer-reviewed conference proceedings. 
Table 5. Geographical Grouping of UAA Institution/Organization Memberships, 2010

\begin{tabular}{|c|c|c|c|}
\hline $\begin{array}{c}\text { Geographical } \\
\text { Region } \\
\end{array}$ & $\begin{array}{c}\text { UAA } \\
\text { Memberships } \\
\end{array}$ & $\begin{array}{c}\text { Percent of Total } \\
\text { UAA Membership }\end{array}$ & $\begin{array}{c}\text { Percent of } \\
\text { CAR Articles } \\
\end{array}$ \\
\hline Great Lakes & 22 & 22.45 & 46.49 \\
\hline Southern & 17 & 17.35 & 26.32 \\
\hline Southwest & 14 & 14.29 & 5.86 \\
\hline Eastern & 13 & 13.26 & 1.76 \\
\hline Northwest Mountain & 10 & 10.20 & 4.38 \\
\hline Central & 7 & 7.15 & 7.58 \\
\hline Western Pacific & 6 & 6.12 & 5.86 \\
\hline New England & 4 & 4.08 & 1.17 \\
\hline Alaska & 1 & 1.02 & 0.00 \\
\hline Non-US & 4 & 4.08 & 0.58 \\
\hline Total & 98 & 100.00 & 100.00 \\
\hline
\end{tabular}

A review of contributions from all of those years revealed many interesting findings:

1. Institutional/organizational affiliation of contributing authors.

- Authors representing 54 different institutions/organizations and 1 non-affiliation were identified as CAR contributors

- The top ten contributors, all educational institutions, accounted for $72 \%$ of total CAR articles

- Universities and colleges accounted for $97 \%$ of the CAR article contributions

- Very few non-academic organizations have published in the CAR during its 28year history

2. Contributors and subject matter of $C A R$ articles.

- There were 35 co-authors contributing to 75 total $C A R$ articles published between 1983 and 2000. During the last 10 years (2001-2010), there have been 118 coauthors contributing to 114 total CAR articles

- The top five institutions (Southern Illinois, Middle Tennessee State, Purdue, Auburn, and Embry-Riddle), ranked by total number of CAR author-credited articles (174), contributed to 51\% of total CAR articles published from 1983-2010

- The subject matter contributions were diverse, but heavily concentrated in the areas of collegiate flight training, collegiate aviation degree programs, the collegiate aviation student, the airport system (including air traffic control), and the commercial airline industry

3. Geographic grouping of $C A R$ article authorship.

- Authors associated with institutions/organizations located in the Great Lakes region have contributed significantly to the $C A R$ over the years, primarily due to 
Southern Illinois University's domination of total author-credited articles (79 articles or 23\%)

- Authors associated with institutions/organizations located in the Southern region have also contributed a large percentage of CAR articles (26\%)

- Only two international authors/institutions (both from Canada) have contributed to the $C A R$ over the past 28 years

\section{Discussion}

Regarding the next 28 years of the Collegiate Aviation Review and the University Aviation Association, several conclusions can be made based on the outcome of this study:

1. The large participation by the Great Lakes and Southern regions, in terms of both UAA membership and CAR authorship, is likely to continue. The collegiate aviation programs at educational institutions located in these two regions are well-established and possess large numbers of degree programs, aviation student populations, and faculty members. All three of these factors contribute favorably to increases in UAA membership numbers as well as contributing authors to the CAR.

2. Academia, university, and college faculty will continue to lead the way in author contributions to the $C A R$, primarily because the spirit of academia is to encourage and reward faculty to engage in scholarly activity (tenure and promotion). Many aviation professionals and practitioners outside of the educational institutions have less of an incentive to devote quality time required to research, write, and publish a $C A R$ article.

3. Given the collegiate nature and aviation expertise of the UAA's membership; collegiate flight training curriculum and instructional methods, the collegiate aviation student, collegiate aviation degree programs, the airport system, and the commercial airline industry will continue to be the subjects of choice by the universities and colleges. However; as indicated in the past 28 years, the contributing authors to the $C A R$ will continue to research the current challenges and issues occurring every day in the aviation industry, as well as the collegiate flight environment.

4. Forty-seven percent, 89 of 189, of total $C A R$ articles had contributing authors. However, only $20 \%$ of these articles (18) had contributing authors from different institution/organization affiliations. All in all, less than $10 \%$ of all CAR articles (189) were co-authored by different institutions/organizations; suggesting that very few aviation faculty members are collaboratively engaging in research initiatives with colleagues from other educational institutions and aviation/aerospace organizations.

5. There is very little international influence in the Collegiate Aviation Review. Over the 28-year history of the journal, only two authors representing two international educational institutions have contributed their aviation knowledge and experiences. As a result, only a minute number of $C A R$ articles (1.7\%) have focused on international aviation issues. However; in regards to the UAA institutional 
membership directory for 2010, only 4\% of membership were from international institutions/organizations.

6. In 1983, the first year that conference proceedings were published, the UAA had 36 institutional memberships and 188 individual members (C. Williamson, personal communication, November 16, 2011). There were a total of 5 articles (79 pages) published in the 1983 proceedings. By 2010, the UAA had 98 institutional memberships and 500 individual members; and 14 articles (201 pages) were published in the 2010 CAR (spring and fall issues). In addition, from 2006-2010, $39 \%$ of the total 189 articles were published in the CAR. Therefore, the growth in UAA membership since 1983 correlates with the increase in published CAR articles during the past 28 years; supporting the UAA goal of "furnishing a national vehicle (the $C A R$ ) for the dissemination of knowledge relative to aviation among institutions of higher education and governmental and industrial organizations in the aviation/aerospace field” (Fanjoy, 2008, p. 6).

\section{Recommendations}

In summary, this exploratory study presented as many questions as it hopefully answered. Examples of questions and subsequent recommendations related to further study include:

1. Over the past 28 years, what has been the acceptance rate versus the rejection rate of academic manuscripts submitted to the CAR for review? One method of evaluating the rank of an academic journal is to review the acceptance rate and rejection rate percentages to determine how competitive that journal is relative to the other journals within the same academic discipline (St. John's University, 2004).

2. Are UAA members consistently submitting their research manuscripts to other aviation scholarly journals? If so, what are the various reasons for not submitting to the CAR? Perhaps the research orientation at certain UAA educational institutions or an individual faculty member's line of inquiry precludes them from submitting their research to the CAR. Should there be changes made to the CAR to better fulfill the goals and desires of the UAA and its existing membership, as well as prospective scholars and members?

3. Why are very few UAA members collaboratively engaging in research initiatives with colleagues from other educational institutions and/or aviation organizations? Perhaps this can be attributed to the fact that some educational institutions do not promote peer collaboration from other institutions or that some educational institutions' tenure/promotion documents prefer single authorship research initiatives.

4. How can the UAA effectively expand its reach into the global aviation education marketplace? Educational institutions in the U.S. and the international communities will need to increase their collaborative effort in order to reach common solutions that respond to everyone's needs associated with the aviation industry. Even though different perspectives and different disciplines may exist; 
an interdisciplinary approach of working together must be fostered to find feasible solutions to the numerous issues facing aviation in a global world. 


\section{References}

Daley, J. M. (Ed.). (1983). Acknowledgments. 1983 Proceedings: University Aviation Association Fall Educational Conference, iii.

Fanjoy, R. O. (2008). Statement of objectives. Collegiate Aviation Review, 26(2), 6.

Federal Aviation Administration. (2011). Regions and aeronautical center operations. Retrieved from http://www.faa.gov/about/office_org/headquarters_offices/arc/ index.cfm?print=go

McCoy, C. E. (1991). Acknowledgements. Collegiate Aviation Review, 9(1), i.

St. John's University. (2004). Journal rankings \& acceptance rates. Retrieved from http://www.stjohns.edu/academics/libraries/resources/journals.stj

University Aviation Association. (2011a). University Aviation Association historical timeline. Retrieved from http://www.uaa.aero/default.aspx? scid $=$ MzqJSe1trfo $=\& m p=0$

University Aviation Association. (2011b). UAA membership list: Institutional. Retrieved from http://www.uaa.aero/sitefiles/uaa/members/Mbrlist_2011_02_Inst.pdf

University Aviation Association. (2011c). Collegiate Aviation Review Online. Retrieved from http://www.uaa.aero/members/default.aspx?scid=xtDumaTIXiw=

Woods, M. D., Nelson, J. R., \& Bliss, T. J. (1989). Eighteen years of the Journal of the Community Development Society: Where have we been? Where are we going? Journal of the Community Development Society, 20(1), 55-69. 